\title{
Deep Learning with Multiband Synthesis from Landsat-8 Satellite Imagery using Machine Learning
}

\author{
C. Rajabhushanam, Velvizhi R, Amudha S
}

\begin{abstract}
This examination article proposes a novel profound learning portrayal and division approach for moderate goals remote detecting picture investigation. An information extraction approach utilizing profound various leveled understanding for remote detecting picture is embraced as a proving ground for further increment in spatial goals symbolism. The thought is the way that we can receive a speedy filtering picture division in a profound learning highlight portrayal structure utilizing a profound learning method to deliver sensible measured bunches in portioned locales until it frames a super-object. Our commitment is to actualize a viable system for multi-scale picture investigation to address the issue of estimating vulnerability by and by.

We at that point propose to test our strategy on two high goals remote detecting picture datasets that will yield brings about the type of multi-layered scenes that bear witness to the proficiency and unwavering quality of our proposed framework.

Keywords: Hierarchical Scale Space, Hierarchical Image Analysis, Scene Segmentation, Deep learning, Convolution Neural Networks, Satellite Imagery.
\end{abstract}

\section{INTRODUCTION}

Feature Selection for scene analysis is vital for feature object understanding that is very crucial for scene recognition that has been a focus of a lot of research studies on feature extraction from high resolution remote sensing images. Feature extraction delineates the objects into simple regions with homogeneous classes for the proper layout of image contents[1],[3],[5]. It is therefore a great challenge in computer vision and pattern recognition for representation of features with accuracy and timeliness. Due to automation tasks in the process some geometries of the target objects are not delineated accurately which is then represented as uncertainty in final image analysis[2],[4],[6].

There exists techniques for feature selection from labeled and unlabeled images that will adopt the learned features to accurately train the classifier, which then can be used in feature extraction in the new classified images. There have been some recent developments in this area of research that factor in high-dimensional data like multi-spectral and high resolution satellite images[26],[28],[30]. Recently, deep

Revised Manuscript Received on July 22, 2019.

C. Rajabhushanam, Department of Computer science and Engineering, Bharath Institute of Higher Education and Research, Chennai, Tamilnadu, India. Email: rajabhushanamc.cse@bharathuniv.ac.in

Velvizhi R, Department of Computer science and Engineering, Bharath Institute of Higher Education and Research, Chennai, Tamilnadu, India. Email: velvizhisp@gmail.com

Amudha S, Department of Computer science and Engineering, Bharath Institute of Higher Education and Research, Chennai, Tamilnadu, India. Email: amudha17s@gmail.com learning methods have generated models from unlabeled data that result in deep neural networks for object analysis and scene classification.

In this research article, we propose a method that produces hierarchical scale space images from input datasets that will be input to the segmentation method under deep learning framework[7],[9],[11].

\section{METHODOLOGY}

A feature extraction method using multi-scale and hierarchical representations of remote sensing image is described. We develop a quick scene segmentation and a deep hierarchical feature selection framework in order to develop an automated workflow for multi-scale remote sensing images to produce an efficient image analysis technique[8],[10],[12] . The framework of our proposed strategy is shown in figure 1. The high resolution satellite image is pre-processed to produce over-segmentation with fuzzy learning rules with clustering. Then a Region Adjacency Graph of the segmented scene is produced hierarchically in a deep learning framework. The multi-scale feature understanding is constructed to output a set of object segmented scene.

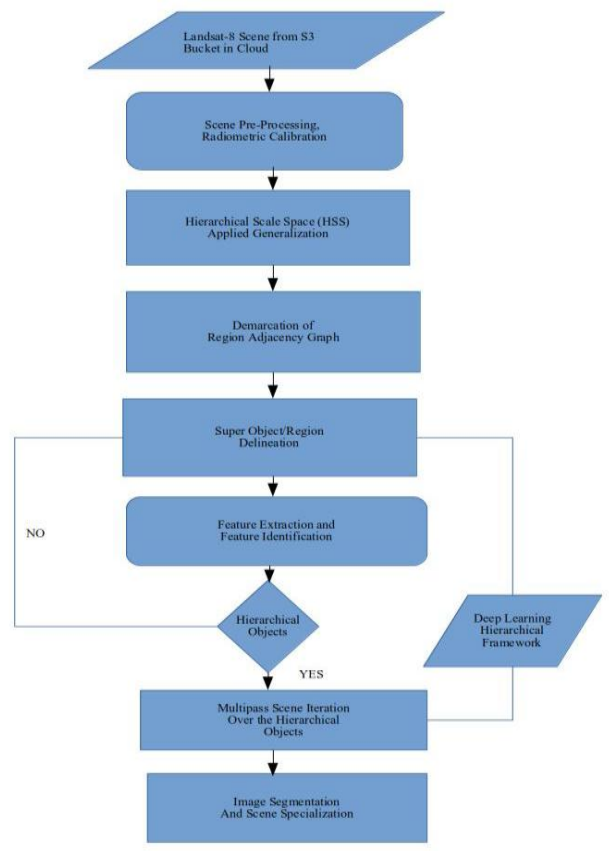

Figure 1 - Architecture

\section{PROPOSED ALGORITHM}

i) Hierarchical scale space created pictures of an average scene are delivered to produce the apriori sections of super

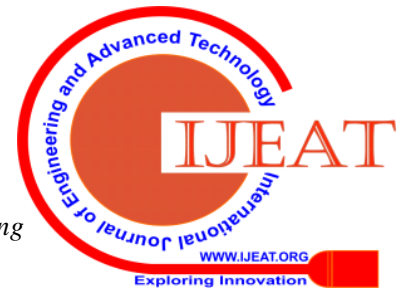


protests with differing sigma (scale parameter). At that point, not at all like district developing there isn't a need of seed highlights for the underlying super article classes that thusly is hung over the edges of highlight limits from left-to-right corners of the picture covering the whole scene. Highlight depiction for consolidating and parting is performed by Spatial Fuzzy C-Means bunching calculation[13],[15],[17].

ii) Developing a Region Adjacency Graph (RAG) that identifies with edge pixels gives a spatial perspective on the scene[14],[16],[18]. The RAG procedure relates a vertex from every locale with an edge in each pair of contiguousness districts. The chart's component outlines a section that the diagram's edge speaks to as a way more than two districts, protecting the picture neighborhood objects.

iii) Feature extraction and converging from districts recognized beforehand are combined again dependent on profound learning system. The district consolidating technique is a base up procedure that concentrates areas under specific criteria (spatially adjoining and similitude file). Locale combining depends on Deep Neural Networks and highlight learning in a solo strategy. Highlight parting and consolidating is iteratively performed until conclusive articles are separated and spoke to.

iv) The numerous layered element extraction technique is intended to yield a lot of progressively portions from information satellite symbolism dataset[19],[21],[23]. A one of a kind part of this strategy is that all edges are differentiated at the ideal spatial goals of the symbolism dataset. The division levels are utilized for highlight determination in the locale of enthusiasm (Contouring).

The iterative procedure will be directed on Landsat- 8 scene of Chennai City with $30 \mathrm{~m}$ spatial goals (Figure 2) and dataset from Cartosat-2 scene with $2.5 \mathrm{~m}$ goals[20],[22],[24].

As depicted above, scene goals takes into consideration mimicking the size of human vision to create increasingly more itemized article chains of command. The scene can be imagined by the examination of versatile scales as indicated by the area of choice[25],[27],[29]. The extraordinary portrayal is that this methodology identifies with the idea of progressive picture includes that are critical at a few scale levels.

\section{RESULTS}

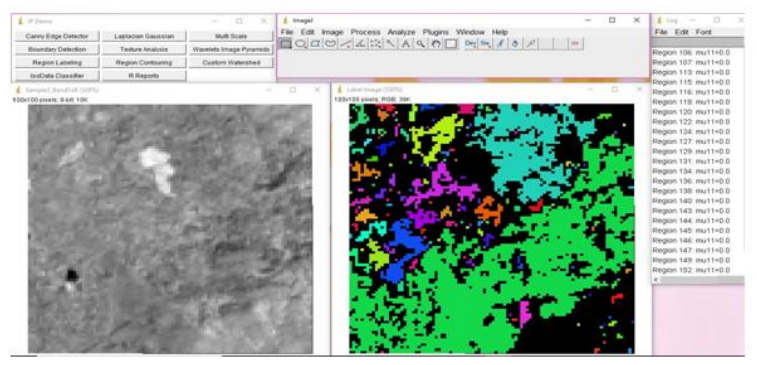

Figure 2: Region Labeling for Landsat-8 Scene (Hierarchical framework)

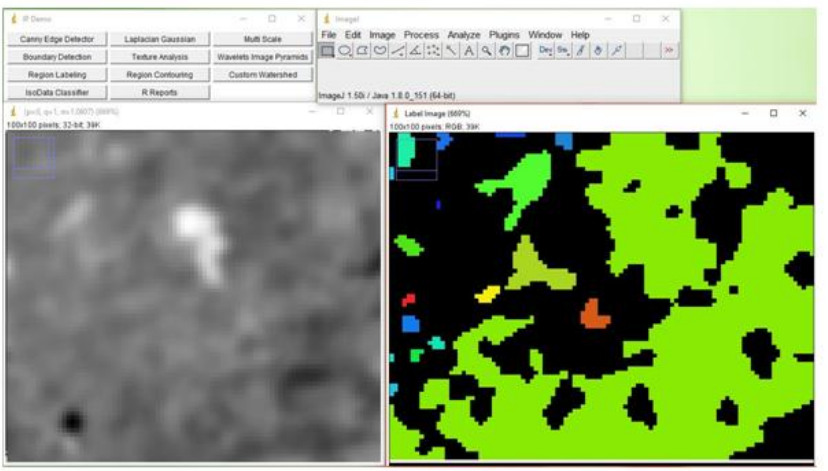

Figure 3: Multiscale analysis of Landsat-8 Scene with Region Labeling

\section{REFERENCES}

1. Gowri Sankaran, B., Karthik, B. \& Vijayaragavan, S.P. 2019, "Weight ward change region plummeting change for square based image huffman coding", International Journal of Innovative Technology and Exploring Engineering, vol. 8, no. 10, pp. 4313-4316.

2. Gowri Sankaran, B., Karthik, B. \& Vijayaragavan, S.P. 2019, "Image compression utilizing wavelet transform", International Journal of Innovative Technology and Exploring Engineering, vol. 8, no. 10, pp. 4305-4308.

3. Kandavel, N. \& Kumaravel, A. 2019, "Offloading computation for efficient energy in mobile cloud computing", International Journal of Innovative Technology and Exploring Engineering, vol. 8, no. 10, pp. 4317-4320.

4. Vinoth, V.V. \& Kanniga, E. 2019, "Reversible data hiding in encrypting images-an system", International Journal of Engineering and Advanced Technology, vol. 8, no. 6, pp. 3051-3053.

5. Selvapriya, B. \& Raghu, B. 2019, "Pseudocoloring of medical images: A research", International Journal of Engineering and Advanced Technology, vol. 8, no. 6, pp. 3712-3716.

6. Senthil Kumar, K. \& Muthukumaravel, A. 2019, "Bi-objective constraint and hybrid optimizer for the test case prioritization", International Journal of Engineering and Advanced Technology, vol. 8, no. 6, pp. 3436-3448.

7. Kavitha, G., Priya, N., Anuradha, C. \& Pothumani, S. 2019, "Read-write, peer-to-peer algorithms for the location-identity split", International Journal of Innovative Technology and Exploring Engineering, vol. 8, no. 9 Special Issue 3, pp. 445-447.

8. Kaliyamurthie, K.P., Michael, G., Anuratha, C. \& Sundaraj, B. 2019 , "Certain improvements in alzheimer disease classification using novel fuzzy c means clustering for image segmentation", International Journal of Innovative Technology and Exploring Engineering, vol. 8, no. 9 Special Issue 3, pp. 599-604.

9. Kaliyamurthie, K.P., Sundarraj, B., Geo, A.V.A. \& Michael, G. 2019, "RIB: Analysis of I/O automata", International Journal of Innovative Technology and Exploring Engineering, vol. 8, no. 9 Special Issue 3, pp. 1019-1022.

10. Velvizhi, R., Rajabhushanam, C. \& Vidhya, S.R.S. 2019, "Opinion mining for travel route recommendation using Social Media Networks (Twitter)", International Journal of Innovative Technology and Exploring Engineering, vol. 8, no. 9 Special Issue 3, pp. 508-512.

11. Kavitha, R., Sangeetha, S. \& Varghese, A.G. 2019, "Human activity patterns in big data for healthcare applications", International Journal of Innovative Technology and Exploring Engineering, vol. 8, no. 9 Special Issue 3, pp. 1101-1103.

12. Pothumani, S., Anandam, A.K., Sharma, N. \& Franklin, S. 2019, "Extended VEOT framework - Implemented in a smart boutique", International Journal of Innovative Technology and Exploring Engineering, vol. 8, no. 9 Special Issue 3, pp. 762-767.

13. Kaliyamurthie, K.P., Michael, G., Krishnan, R.M.V. \& Sundarraj, B. 2019, "Pseudorandom techniques for the internet", International Journal of Innovative Technology and Exploring Engineering, vol. 8, no. 9 Special Issue 3, pp. 915-918.

14. Aravindasamy, R., Jeffrin Rajan, M., Rama, A. \& Kavitha, P. 2019, "Deep learning provisions in the matlab: Focus on CNN facility", International Journal of Innovative Technology and Exploring Engineering, vol. 8, no. 9 Special Issue 3, pp. 990-994.

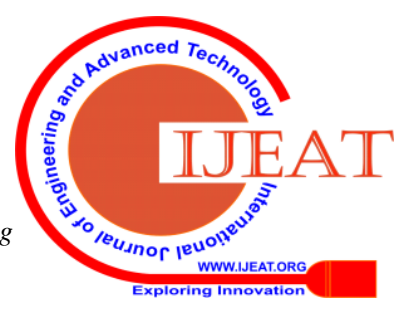


15. Theivasigamani, S., Linda, M. \& Amudha, S. 2019, "Object sensing and its identification \& motion sensing", International Journal of Innovative Technology and Exploring Engineering, vol. 8, no. 9 Special Issue 3, pp. 545-549.

16. Mary Linda, I., Vimala, D. \& Shanmuga Priya, K. 2019, "A methodology for the emulation of IPv4", International Journal of Innovative Technology and Exploring Engineering, vol. 8, no. 9 Special Issue 3, pp. 848-852.

17. Velvizhi, R., Priya, D.J., Vimala, D. \& Linda, I.M. 2019, "Increased routing algorithm for mobile adhoc networks", International Journal of Innovative Technology and Exploring Engineering, vol. 8, no. 9 Special Issue 3, pp. 1606-1608.

18. Sangeetha, S., Anuradha, C. \& Priya, N. 2019, "DNS in real world", International Journal of Innovative Technology and Exploring Engineering, vol. 8, no. 9 Special Issue 3, pp. 937-940.

19. Geetha, C., Vimala, D. \& Priya, K.S. 2019, "Constructing multi-processors and spreadsheets with SKIVE", International Journal of Innovative Technology and Exploring Engineering, vol. 8, no. 9 Special Issue 3, pp. 516-519.

20. Yugendhar, K., Sugumar, V. \& Kavitha, P. 2019, "A novel method of univac using fuzzy logic", International Journal of Innovative Technology and Exploring Engineering, vol. 8, no. 9 Special Issue 3, pp. 435-437.

21. Kaliyamurthie, K.P., Michael, G., Elankavi, R. \& Jijo, S.A. 2019, "Implementing aggregate-key for sharing data in cloud environment using cryptographic encryption", International Journal of Innovative Technology and Exploring Engineering, vol. 8, no. 9 Special Issue 3, pp. 957-959.

22. Jeffrin Rajan, M., Aravindasamy, R., Kavitha, P. \& Rama, A. 2019, "A novel method of object orientation variation in C++ and java", International Journal of Innovative Technology and Exploring Engineering, vol. 8, no. 9 Special Issue 3, pp. 708-710.

23. Nayak, R., Dinesh, S. \& Thirunavukkarasu, S. 2019, "A novel method improvement of rapid miner for the data mining applications", International Journal of Innovative Technology and Exploring Engineering, vol. 8, no. 9 Special Issue 3, pp. 457-460.

24. Sivaraman, K., Krishnan, R.M.V., Sundarraj, B. \& Sri Gowthem, S. 2019, "Network failure detection and diagnosis by analyzing syslog and SNS data: Applying big data analysis to network operations", International Journal of Innovative Technology and Exploring Engineering, vol. 8, no. 9 Special Issue 3, pp. 883-887.

25. Vimala, D., Linda, I.M. \& Priya, K.S. 2019, "Decoupling online algorithms from erasure coding in DNS", International Journal of Innovative Technology and Exploring Engineering, vol. 8, no. 9 Special Issue 3, pp. 950-953.

26. Rama, A., Kumaravel, A. \& Nalini, C. 2019, "Preprocessing medical images for classification using deep learning techniques", International Journal of Innovative Technology and Exploring Engineering, vol. 8, no. 9 Special Issue 3, pp. 711-716.

27. Sangeetha, S., Srividhya, S.R., Anita Davamani, K. \& Amudha, S. 2019, "A procedure for avoid overrun error in universal synchronous asynchronous receiver transmitter (usart) by utilizing dummy join and interrupt latency method", International Journal of Innovative Technology and Exploring Engineering, vol. 8, no. 9 Special Issue 3, pp. 657-660.

28. Aravindasamy, R., Jeyapriya, D., Sundarajan, B. \& Sangeetha, S. 2019, "Data duplication in cloud for optimal performance and security", International Journal of Innovative Technology and Exploring Engineering, vol. 8, no. 9 Special Issue 3, pp. 1156-1158.

29. Aravindasamy, R., Jeffrin Rajan, M., Sugumar, V. \& Kavitha, P. 2019, "A novel method on developing superblocks and the transistor using apodryal", International Journal of Innovative Technology and Exploring Engineering, vol. 8, no. 9 Special Issue 3, pp. 982-985.

30. Sasikumar, C.S. \& Kumaravel, A. 2019, "E-learning attributes selection through rough set theory and data mining", International Journal of Innovative Technology and Exploring Engineering, vol. 8, no. 10 , pp. $3920-3924$

\section{AUTHORS PROFILE}

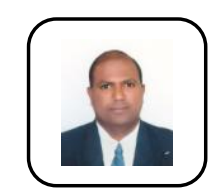

C. Rajabhushanam Professor, Department of Computer science and Engineering, Bharath Institute of Higher Education and Research, Chennai, India

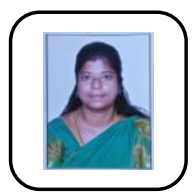

Velvizhi R Assistant Professor, Department of Computer science and Engineering, Bharath Institute of Higher Education and Research, Chennai, India

Amudha S Assistant Professor, Department of Computer science and Engineering, Bharath Institute of Higher Education and Research, Chennai, India 